\title{
A partial physical map for the chromosome of alkalophilic Bacillus sp. strain C-125
}

\author{
Katharine J. Sutherland, $\uparrow$ Michizane Hashimoto, Toshiaki Kudo* and Koki Horikoshi
}

The RIKEN Institute and JRDC, Hirosawa 2-1, Wako-shi, Saitama, 351-01, Japan

(Received 21 August 1992; revised 16 November 1992 accepted 24 November 1992)

\begin{abstract}
Bacillus sp. strain $\mathrm{C}-125$ has been chosen as a model alkalophilic bacterium to understand how adaptation to growth at high pH is achieved. To aid genetic analysis, we have started characterization of its genome. By using the two infrequently-cutting restriction endonucleases, $A s c I$ and $S s e 8387$, in conjunction with pulsed-field electrophoretic techniques, the size of the genome was found to be 3.7 Mb. Southern blot analysis of single, double and partial digests of Bacillus sp. strain C-125 DNA, using AscI-linking clones, gene probes and purified Bacillus sp. strain C-125 restriction fragments, allowed a putative chromosome map to be constructed.
\end{abstract}

\section{Introduction}

How extremophiles are adapted to living in their extreme environments is one of the most interesting and challenging questions facing microbiologists today. Our group has a specific interest in alkalophilic bacteria and has been using a molecular biological approach to attempt to understand how they are adapted to living at high $\mathrm{pH}$.

Detailed genetic and physical maps are available for the Bacillus subtilis 168 chromosome (Piggot \& Hoch, 1989; Itaya \& Tanaka, 1991). In addition, a physical map of the Bacillus cereus chromosome has been constructed (Kolsto et al., 1990). To aid our studies on alkalophiles, we decided to construct a physical map for the alkalophilic Bacillus sp. strain C-125 chromosome. Alkalophilic Bacillus sp. strain C-125 was chosen as a model alkalophile since (i) it exhibits the standard alkalophilic properties of growing between $\mathrm{pH}$ 7.5 and 11 , and of requiring $\mathrm{Na}^{+}$for growth; (ii) it grows well on minimal medium, allowing cloning of genes by a selective marker and complementation approach; (iii) an efficient transformation system for cloning in Bacillus sp. strain C-125 is available; (iv) several genes have been cloned from this strain and thus can be used as markers on its chromosome map; and finally (v) we believe, on

\footnotetext{
*Author for correspondence

$†$ Present address: Department of Molecular Medicine, Collier Building, Royal Postgraduate School of Medicine, DuCane Road, London, W12 0NN, UK.
}

the basis of GC content (Horikoshi, 1991) and gene sequence comparisons (Kang et al., 1992), that this strain is closely related to B. subtilis 168 for which detailed physical and genetic maps are already available (Itaya \& Tanaka, 1991; Piggot \& Hoch, 1989).

The last few years have seen an escalation in the number of maps reported in the literature. Many different methods have been used to construct these physical maps. For example, two-dimensional pulsedfield gel electrophoresis (2D PFGE) was used to construct a physical map of the Pseudomonas aeruginosa PAO genome (Römling et al., 1989; Römling \& Tümmler, 1991). Other methods involving the probing of complete or partial digests with gene probes or linking clones (as described by Smith \& Condemine, 1990) or with large overlapping restriction fragments have been used successfully (Taylor et al., 1992; Yan \& Taylor, 1991; Krause \& Mawn, 1990; Chen et al., 1991 ; Fonstein et al., 1992); and an interesting gene-directed mutagenesis method whereby restriction sites were removed by point mutations was employed by Itaya \& Tanaka (1991) to construct the physical map of the B. subtilis chromosome. Often a combination of two or more methods is required, as for example in the mapping of the Chlamydia trachomatis genome (Birkelund \& Stephens, 1992).

This report describes evidence generated by using the two rare-cutting enzymes $A s c \mathrm{I}$ and $S s e 8387 \mathrm{I}$ that suggests the size of the Bacillus sp. strain C- 125 genome is approximately $3.7 \mathrm{Mb}$. The $A s c$ I fragments have been partially ordered using (i) AscI linking clones, (ii) Southern hybridization of single, double and partial 
digests and (iii) cross-hybridization with purified fragments generated by restriction endonuclease digestion of the Bacillus sp. strain C-125 genome. A putative chromosome map is proposed. Hybridization probes derived from cloned genes from Bacillus sp. strain $\mathrm{C}-125$ and $B$. subtilis 168 were used to locate the positions of these genes on the proposed Bacillus sp. strain C-125 chromosome map.

\section{Methods}

Bacterial strains and media. Alkalophilic Bacillus sp. strain C-125 $10596\left(\mathrm{Trp}^{-} \mathrm{Ura}^{-} \mathrm{Cm}^{5}\right)$ was isolated in our laboratory (Honda et al., 1985; Kudo et al., 1990). It was grown on Horikoshi-II medium ( $\mathrm{pH}$ $10.3)$ containing $1 \%(\mathrm{w} / \mathrm{v})$ soluble starch, $0.5 \%$ yeast extract, $0.5 \%$ polypeptone, $0.1 \% \mathrm{~K}_{2} \mathrm{HPO}_{4}, 0.02 \% \mathrm{MgSO}_{4} .7 \mathrm{H}_{2} \mathrm{O}$, and $1 \%(\mathrm{w} / \mathrm{v})$ $\mathrm{Na}_{2} \mathrm{CO}_{3}$ (sterilized separately). Cloning of the Bacillus DNA was carried out in Escherichia coli MV1184 (ara $\Delta$ (lac-proAB) rpsL thi $(\phi 80$ lacZ $\Delta \mathrm{M} 15) \Delta\left(\right.$ srl-recA)306:: $\operatorname{Tn} 10\left(\right.$ tet $\left.^{\prime}\right) \mathrm{F}^{\prime}\left[\right.$ traD 36 proAB lacI ${ }^{q}$ lac $Z$ $\Delta \mathrm{M} 15]$ ). $E$. coli was grown on $2 \times$ yeast/tryptone medium (Sambrook et al., 1989).

Plasmids, enzymes and chemicals. Restriction endonucleases Asc I, $P a c I$, and pNEB193 vector were from New England Biolabs. Sse8387I, other restriction endonucleases and $\mathrm{T}_{4}$ DNA ligase were from Takara Shuzo Co. The DIG DNA labelling and detection kit was from Boehringer Mannheim. Hybond $\mathrm{N}^{+}$membrane was from Amersham International. InCert agarose and $\lambda$ DNA ladders were from FMC BioProducts.

Preparation of insert and digestion of chromosomal DNA. Cells of Bacillus sp. strain C-125 were harvested from a $10 \mathrm{ml}$ stationary-phase culture. The cells were washed once in TE buffer ( $10 \mathrm{mM}$ Tris, $\mathrm{pH} \mathrm{8.0,}$ 1 mM-EDTA) before being resuspended in $0.25 \mathrm{ml}$ TE buffer. The following were then added to the cell suspension: $20 \mu 110 \mathrm{mg} \mathrm{ml}^{-1}$ RNAase A, $200 \mu \mathrm{l} 0.1 \mathrm{mg} \mathrm{ml}^{-1}$ lysozyme, and $1 \mathrm{ml} 1.5 \%(\mathrm{w} / \mathrm{v})$. InCert agarose solution (made in TE buffer). The solution was vortexed briefly before being poured into a single well of a 24-well Falcon tissue culture plate. The plate was placed at $-20^{\circ} \mathrm{C}$ for $2 \mathrm{~min}$. The solidified gel was then cut into $8-10$ pieces using a flamed spatula

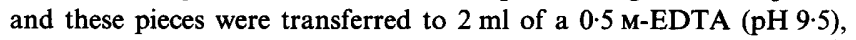
$1 \% \mathrm{~N}$-lauroylsarcosine solution containing $2 \mathrm{mg}$ proteinase $\mathrm{K} \mathrm{ml}^{-1}$. The plugs were incubated at $50^{\circ} \mathrm{C}$ for $24 \mathrm{~h}$. They were then washed 5 times with TE buffer (room temperature [RT] for $15 \mathrm{~min}$ ), once with 0.1 mM-PMSF (RT for $1 \mathrm{~h}$ ) and 3 times with TE buffer (RT for $15 \mathrm{~min}$ ). Plugs prepared as above were stored indefinitely in TE buffer at $4{ }^{\circ} \mathrm{C}$ until required for digestion. For digestion, a portion of a DNA plug $(25-50 \mu \mathrm{l}$ in volume) was incubated twice in $200 \mu \mathrm{l}$ of the appropriate $1 \times$ digestion buffer (RT for $15 \mathrm{~min}$ ) and then in $100 \mu \mathrm{l} 1 \times$ digestion buffer containing 5-20 U restriction endonuclease (at the appropriate temperature for $16 \mathrm{~h}$ ). Partial digestion was achieved by lowering the concentration of enzyme. For loading, the DNA plug reaction mixture was incubated at $65^{\circ} \mathrm{C}$ for $10 \mathrm{~min}$ and then loaded directly on to the gel prior to submerging the latter in the electrophoresis buffer.

Electrophoretic analysis. DNA fragments were resolved in a Pharmacia-LKB Pulsaphor apparatus using a hexagonal array of electrodes. The $1 \%(\mathrm{w} / \mathrm{v})$ agarose gels were subjected to electrophoresis at $14{ }^{\circ} \mathrm{C}$ in $0.5 \times$ TBE buffer $[0.05 \mathrm{M}$-Tris $/ \mathrm{HCl}, 0.05 \mathrm{M}$-boric acid, $2 \mathrm{mM}$ $\mathrm{Na}_{2}$ EDTA. $\left.2 \mathrm{H}_{2} \mathrm{O}(\mathrm{pH} 8.0)\right]$ at $160 \mathrm{~V}$ for $24 \mathrm{~h}$ with a pulse time of 5 to $55 \mathrm{~s}$, varied according to the optimum size of separation desired.

Linking clone isolation. Approximately $2 \mu \mathrm{g}$ genomic DNA from Bacillus sp. strain C-125 prepared by the conventional liquid isolation method of Saito \& Miura (1963) was digested with Enzyme A (HindIII or $E c o \mathrm{RI})$. The digested DNA was circularized by ligation with $\mathrm{T}_{4}$ ligase in a reaction volume of $100 \mu \mathrm{l}\left(16^{\circ} \mathrm{C}\right.$ for $\left.16 \mathrm{~h}\right)$. The circularized DNA was precipitated with ethanol and digested with $A s c$ I. It was ligated to $A s c \mathrm{I}$-bacterial alkaline phosphatase (BAP)-treated pNEB193 vector $\left(16^{\circ} \mathrm{C}\right.$ for $\left.16 \mathrm{~h}\right)$ and the ligation mix was then used to transform competent MV1184 cells. Putative linking clones were identified as recombinants which contained two $A s c$ I sites and two Enzyme A sites, as the pNEB193 vector contains a HindIII and an EcoRI site .

Hybridization analysis. Gels were blotted using a vacuum blotter (Pharmacia LKB) on to Hybond $\mathrm{N}^{+}$. All blots were probed with digoxigenin-labelled probe in a $30 \%(\mathrm{w} / \mathrm{v})$ formamide hybridization solution at $42{ }^{\circ} \mathrm{C}$. Subsequent washing and detection steps were carried out according to instructions provided with the Boehringer Mannheim DIG-detection kit.

Uncloned DNA fragments used as probes were purified from lowmelting point agarose by heating at $65^{\circ} \mathrm{C}$ and extraction using phenol.

\section{Results and Discussion}

\section{Selection of endonucleases and determination of chromosome size.}

Intact chromosomal DNA of Bacillus sp. C-125 was prepared in agarose using a method developed by combining and modifying those of Itaya \& Tanaka (1991) and of Römling et al. (1989), used for B. subtilis and Pseudomonas aeruginosa, respectively.

Restriction endonucleases which recognise an $8 \mathrm{bp}$ sequence were tested for their ability to digest the chromosome. PacI enzyme with the recognition sequence 5'-TTAATTAA-3' generated over 50 fragments of less than $50 \mathrm{~kb}$. This result is perhaps not surprising, since in addition to the likelihood that the $P a c I$ recognition site occurs frequently in regions upstream and downstream of coding sequences, the Bacillus sp. C- 125 chromosome (GC content 43.7\%) (Horikoshi, 1991) has a slight bias for $\mathrm{A}$ and $\mathrm{T}$.

In contrast to results obtained with $B$. subtilis, the chromosome of which contains over 70 Not I sites, Not $\mathrm{I}$ does not digest the Bacillus sp. C-125 chromosome. It is likely, however, that $N o t \mathrm{I}$ sites are present on the Bacillus sp. C-125 chromosome but in a modified form, since when Bacillus sp. C-125 DNA is cloned into E. coli, Not $\mathrm{I}$ digestion occurs (data not shown).

$S f i$ enzyme (with the recognition sequence 5'GGCCNNNNNGGCC-3') generated approximately 20 fragments ranging in size from $20 \mathrm{~kb}$ to $700 \mathrm{~kb}$. However, the restriction pattern was uneven, and smearing made it hard to identify fragments and their sizes accurately. Smearing may have been a result of the increased reaction temperature $\left(50^{\circ} \mathrm{C}\right)$ required for $S f i$ digestion stimulating or enhancing activity of nucleases, and the uneveness of the pattern may have been due to the degenerate nature of the $S f i$ restriction site, some sites being more readily digested than others.

The two remaining enzymes, AscI and Sse8387I, 
Table 1. Sizes of restriction fragments generated by AscI and Sse8387I cleavage of the Bacillus sp. strain $C$-125 genome

\begin{tabular}{ccc}
\hline \hline & \multicolumn{2}{c}{ Size $(\mathrm{kb})$ of fragments generated with: } \\
\cline { 2 - 3 } Band & AscI & Sse8387I \\
\hline number & 570 & 530 \\
1 & 530 & 510 \\
2 & 440 & 430 \\
3 & 420 & 390 \\
4 & 390 & 330 \\
5 & 330 & 265 \\
6 & 250 & 220 \\
7 & 170 & 195 \\
8 & 150 & 165 \\
9 & 125 & 155 \\
10 & 120 & 125 \\
11 & 80 & 105 \\
12 & 45 & 70 \\
13 & 35 & 60 \\
14 & 25 & 55 \\
15 & 20 & 48 \\
16 & $3 \cdot 5$ & 40 \\
17 & & 18 \\
18 & $3703 \cdot 5$ & 3711 \\
Total & & \\
\hline \hline
\end{tabular}

generated 17 and 18 resolvable fragments, respectively. The sizes of these fragments were determined by comparison with size standards on a series of PFGE gels (Fig. 1, Table 1). The mean total genome size of Bacillus sp. C-125, obtained by totalling the sizes of the AscI or Sse8387I fragments, is estimated to be $3707 \mathrm{~kb}$. The $B$. subtilis and $B$. cereus genomes have been estimated to be 4.2 and $5.7 \mathrm{Mb}$ in size, respectively (Itaya \& Tanaka, 1991; Kolsto et al., 1990). Thus, it appears that even among Bacillus species large size differences in the chromosome can be accommodated.

\section{Constructing an AscI physical map}

As the AscI enzyme gave consistently better digestion than the Sse8387I enzyme, we decided to construct a physical map of AscI sites on the Bacillus sp. C-125 chromosome.

Initially, AscI linker clones of Bacillus sp. strain C-125 DNA were used in an attempt to position AscI sites on the map. A linker clone contains DNA which overlaps two adjacent restriction fragments and can be used as a hybridization probe to establish the identity of these two contiguous fragments (Smith \& Condemine, 1990).

Linking clone libraries of approximately 100 clones each were constructed using HindIII or EcoRI as Enzyme A. Plasmid DNA was isolated from individual clones
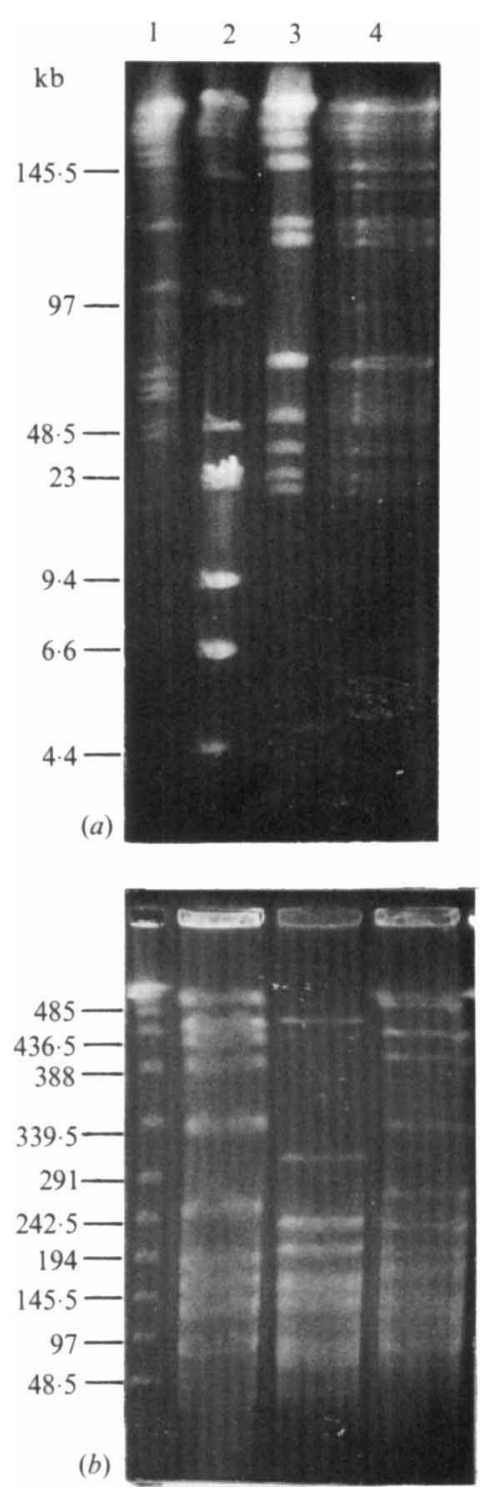

Fig. 1. PFGE of restriction enzyme digests of total DNA from Bacillus sp. strain C-125. (a) Optimal separation conditions for 4-150 kb fragments $\left[1.0 \%(\mathrm{w} / \mathrm{v})\right.$ agarose, $24 \mathrm{~h}, 14^{\circ} \mathrm{C}, 16 \mathrm{~V} \mathrm{~cm}^{-1}, 8 \mathrm{~s}$ pulse time]. Lane 1, Sse8387I; lane 2, lambda standards; lane 3, AscI; lane 4, AscIplus-Sse8387I. (b) Optimal separation conditions for $200-500 \mathrm{~kb}$ fragments $\left[1.0 \%(\mathrm{w} / \mathrm{v})\right.$ agarose, $24 \mathrm{~h}, 14{ }^{\circ} \mathrm{C}, 6 \mathrm{~V} \mathrm{~cm}^{-1}, 40 \mathrm{~s}$ pulse time]. Lane 1, lambda standards; lane 2, AscI; lane 3, AscI plus Sse8387I; lane 4, Sse8387I. Sizes of the standards are shown on the left.

and screened for the presence of two AscI sites and two Enzyme A sites. A total of fourteen possible linker clones were identified and screened for authenticity by Southern blot analysis of Enzyme A-digested Bacillus sp. strain C125 DNA (Fig. 2). Only seven of the fourteen clones (Table 2) proved to be genuine linker clones binding as expected to one Enzyme A fragment, and to two AscI fragments. Table 3 lists the results of using these genuine linker clones for hybridization against AscI-, Sse8387I- 
(a)
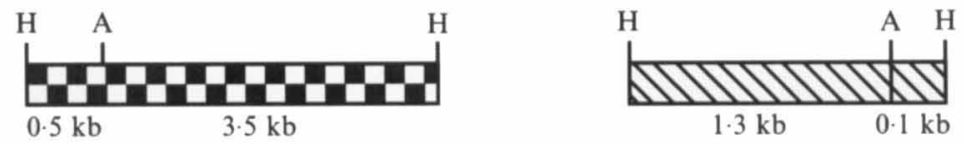

(b)

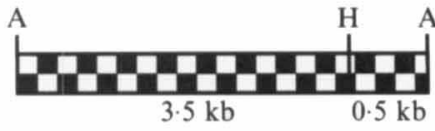

$\mathrm{H} 4$

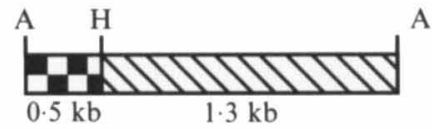

H6

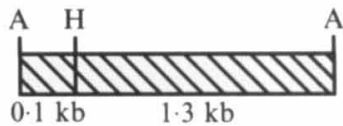

$\mathrm{H} 10$

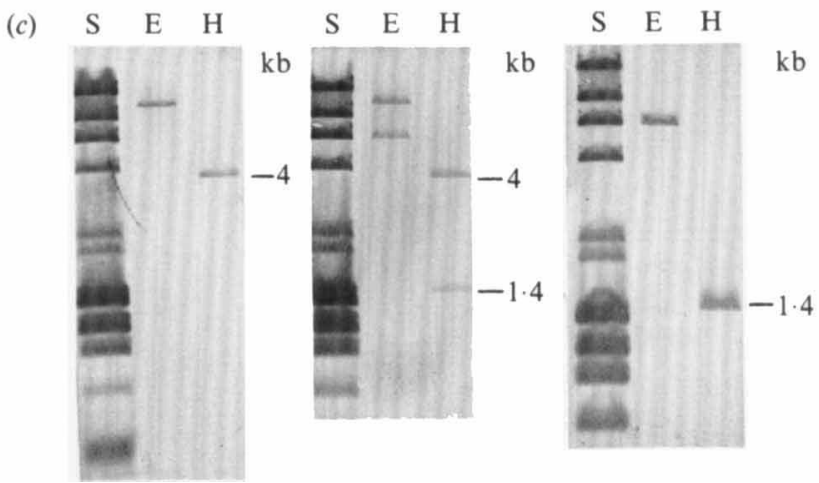

Fig. 2. Check of linker clone authenticity using Southern blot analysis. In these examples, digoxigenin-labelled clones pLINKH4, pLINKH10 and pLINKH6 were used to probe blots $(c)$ containing HindIII (H) digests of Bacillus sp. strain C-125 DNA. [The EcoRI (E) tracks are superfluous and should be ignored]. The clone insert DNA (b) and regions of the chromosome from which these originated (a) are represented schematically as shaded boxes (not to scale). Sizes indicated on the right refer to the hybridized HindIII fragments. Lambda-HindIII/ $\$$ X174-HaeIII markers were hybridized to themselves. A, AscI.

Table 2. Probes and sources

\begin{tabular}{lcll}
\hline \hline Probe & Size $(\mathrm{kb})$ & \multicolumn{1}{c}{ Gene product/phenotype } & Source or reference \\
\hline C-125 uncH,A,G & $2 \cdot 2$ & F 1 ATPase $\alpha, \beta \& \gamma$ subunits & Kobayashi \\
C-125 hag & $2 \cdot 7$ & Flagellin & Sakamoto et al. $(1992)$ \\
C-125 pALK & $0 \cdot 5$ & Alkaline resistance & Kudo et al. $(1990)$ \\
C-125 23S rrn & $3 \cdot 0$ & 23S rRNA & Sutherland \\
C-125 secY & $2 \cdot 0$ & Secretion of proteins & Kang et al. $(1992)$ \\
C-125 xyl(A) & $2 \cdot 6$ & Xylanase (alkaline) & Honda et al. $(1985)$ \\
C-125 xyl(N) & $0 \cdot 9$ & Xylanase (neutral) & Kobayashi \\
B. subtilis trpS & $0 \cdot 9$ & Tryptophanyl tRNA synthase & Chow \& Wong (1988) \\
B. subtilis spoIIG & $0 \cdot 8$ & Stage II sporulation & Stagier et al. $(1984)$ \\
B. subtilis pNEXT39 & $3 \cdot 4$ & B. Subtilis NotI-linking clone & Itaya \& Tanaka (1991) \\
B. subtilis pNEXT41 & $2 \cdot 9$ & B. Subtilis NotI-linking clone & Itaya \& Tanaka (1991) \\
C-125 pLINK H1 & $2 \cdot 9$ & C-125 AscI-linking clone & This study \\
C-125 pLINK H4 & $4 \cdot 0$ & C-125 AscI-linking clone & This study \\
C-125 pLINK H5 & $1 \cdot 5$ & C-125 AscI-linking clone & This study \\
C-125 pLINK H10 & $1 \cdot 4$ & C-125 AscI-linking clone & This study \\
C-125 pLINK H20 & $3 \cdot 7$ & C-125 AscI-linking clone & This study \\
C-125 pLINK H23 & $0 \cdot 7$ & C-125 AscI-linking clone & This study \\
C-125 pLINK E6A & $1 \cdot 5$ & C-125 AscI-linking clone & This study \\
16A fragment & 20 & C-125 AscI fragment (Table 1) & This study \\
\hline
\end{tabular}


Table 3. Hybridization patterns of pLINK clones to restriction endonuclease fragments of Bacillus sp. strain C-125 DNA

Fragments generated with either $A s c I$ or $S s e 8387 \mathrm{I}$ are identified by their band numbers (Table 1). The AscI-plus-Sse8387I fragments and fragments generated as a result of partial AscI or Sse83871 digestion are identified by their sizes in $\mathrm{kb}$.

\begin{tabular}{lrcc}
\hline \hline & \multicolumn{3}{c}{ Hybridization with fragment $(\mathrm{kb})$} \\
\cline { 2 - 4 } Probe & AscI & Sse8387I & $\begin{array}{c}\text { Ascl-plus- } \\
\text { Sse8387I }\end{array}$ \\
\hline pLINK H1 & $17 \mathrm{~A}$ & $6 \mathrm{~S}$ & $17 \mathrm{~A}$ \\
pLINK H4 & $13 \mathrm{~A}$ & & $13 \mathrm{~A}$ \\
& $3 \mathrm{~A}$ & $12 \mathrm{~S}$ & 100 \\
pLINK H5 & $10 \mathrm{~A}$ & & 5 \\
& $11 \mathrm{~A}$ & $1 \mathrm{~S}$ & $11 \mathrm{~A}$ \\
pLINK H10 & $6 \mathrm{~A}$ & & 200 \\
& $14 \mathrm{~A}$ & $7 \mathrm{~S}$ & $14 \mathrm{~A}$ \\
pLINK H20 & $7 \mathrm{~A}$ & & 45 \\
& $5 \mathrm{~A}$ & $17 \mathrm{~S}$ & 18 \\
pLINK H23 & $10 \mathrm{~A}$ & & 30 \\
& $9 \mathrm{~A}$ & $3 \mathrm{~S}$ & $9 \mathrm{~A}$ \\
pLINK E6A & $12 \mathrm{~A}$ & & 60 \\
& $6 \mathrm{~A}$ & $9 \mathrm{~S}$ & 145 \\
& $12 \mathrm{~A}$ & & 20 \\
\hline \hline
\end{tabular}

and $A s c$ I plus Sse8387I-digested Bacillus sp. strain C125 (as illustrated by the example in Fig. 3). Two of the original fourteen clones hybridized to several fragments (even at increased hybridization and washing stringency) and were assumed to contain repetitive DNA sequences from the Bacillus sp. strain C-125 chromosome. The remaining five clones bound to two Enzyme $\mathrm{A}$ fragments. Since a genuine linker clone should bind to only one Enzyme A fragment, it was concluded that these five clones, which appear to be the result of the cloning of two noncontiguous AscI-Enzyme A fragments were artefactual linker clones (e.g. pLinkH6, Fig. 2).

We were unable to isolate all the necessary linking clones required to determine the positions of every $A s c I$ site on the chromosome. Certain AscI sites may be unclonable due to Bacillus gene toxicity in E. coli. Alternatively, they may be contained on very long HindIII or EcoRI fragments that are beyond the limit of plasmid cloning. The latter problem could have been overcome by using alternative enzymes as Enzyme A. However, this would have involved the screening of several hundred more clones, a very time-consuming and expensive exercise.

To obtain more information and to add detail to the map, clones of Bacillus sp. strain C-125 and B. subtilis DNA, and the $20 \mathrm{~kb}$ AscI fragment (Table 2) were used as hybridization probes. The results are listed in Table 4.

Of the B. subtilis clones used, pNEXT39, SpoIIG and

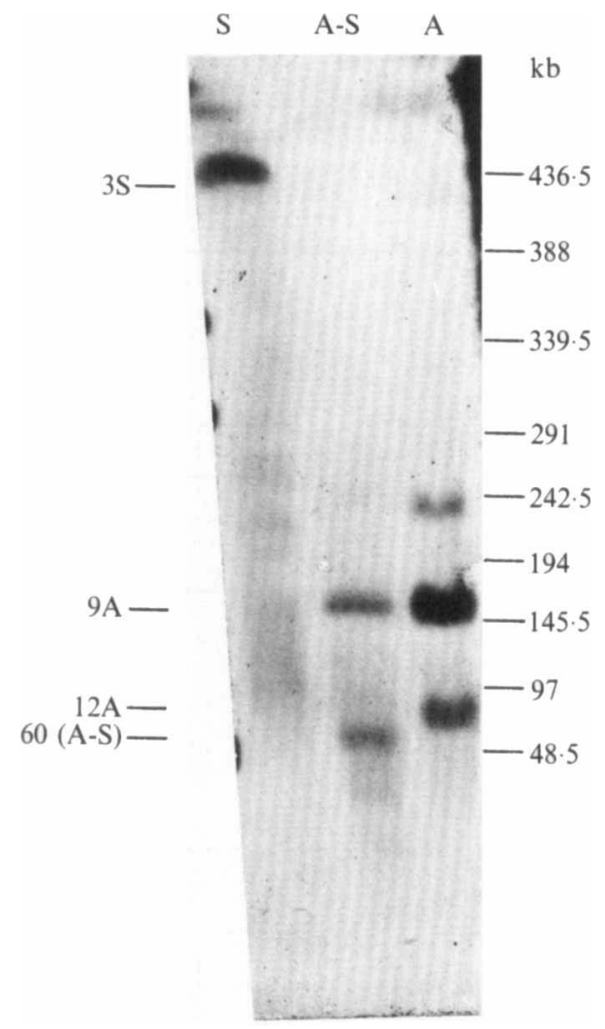

Fig. 3. Southern blot analysis of Bacillus sp. strain C-125 genomic DNA. In this example digoxigenin-labelled pLINKH23 was used to probe a blot containing Sse8387I (S), AscI plus Sse8387I (A-S), and AscI (A) digests of Bacillus sp. strain C-125 DNA. Sizes on the right indicate the migration distance for annealed concatemers of lambda DNA. Positions and identities (as described in Table 1) of observed bands are highlighted on the left. The $230 \mathrm{~kb} \mathrm{AscI}$ fragment is due to partial digestion of the linked $9 \mathrm{~A}$ and $12 \mathrm{~A}$ fragments.

pNEXT41 confirmed results already obtained with the Bacillus sp. strain C-125 clones pALK, pLINKH10 and $x y l(\mathrm{~A})$, respectively. Only $B$. subtilis trpS, important for linking the $8 \mathrm{~A}$ fragment to the $14 \mathrm{~A}$ fragment, generated novel data.

\section{An AscI physical map of the Bacillus sp. strain C-125 chromosome}

The data listed in Tables 3 and 4 have allowed us to arrange the majority of the $A s c \mathrm{I}$ fragments into two regions (Fig. 4). It was not been possible to link all the AscI fragments but, if circularity of the Bacillus sp. strain $\mathrm{C}-125$ chromosome is assumed there are only two possible arrangements for the regions shown in Fig. 4, namely (i, ii, iii, iv) or (i, iv, ii, iii). The binding of the $S e c \mathrm{Y}$ probe to a $460 \mathrm{~kb}$ partial $A s c \mathrm{I}$ fragment, however, rules out arrangement (i, iv, ii, iii). We therefore propose that arrangement (i, ii, iii, iv) (Fig. 5), the only circular 
(i)

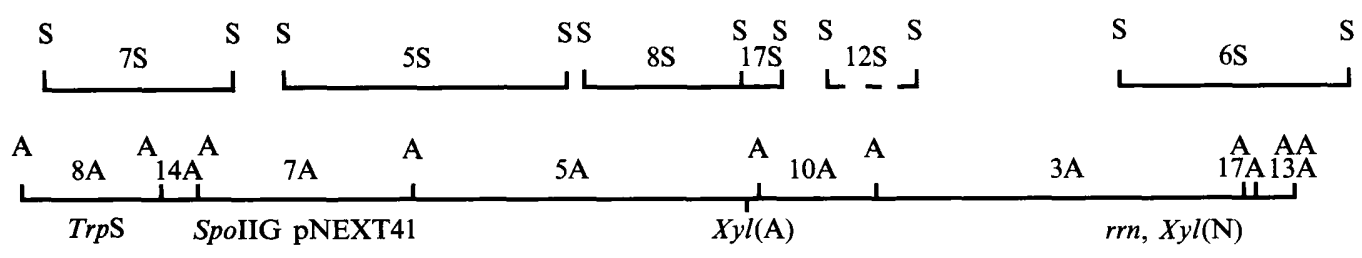

(ii)

\begin{tabular}{llllllll}
$S$ & & $S$ & & $S$ & & & $S$ \\
\hline
\end{tabular}

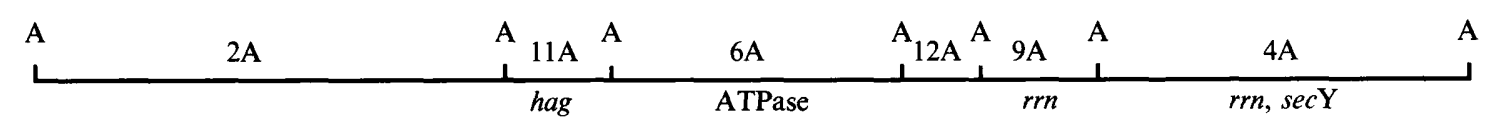

(iii)

(iv)
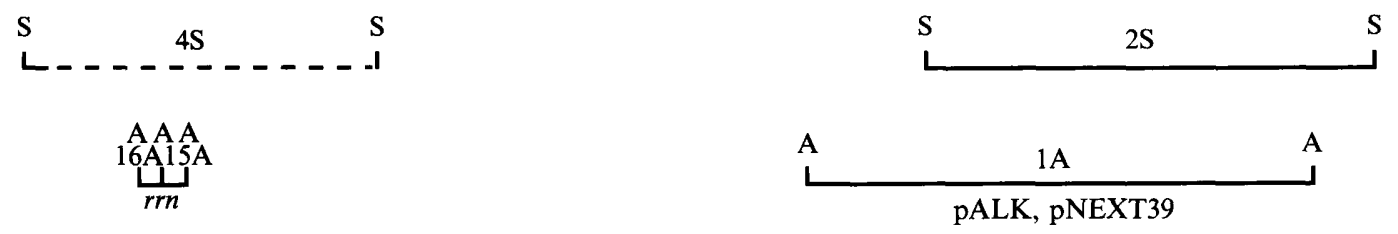

Fig. 4. Partial linkage map of Bacillus sp. strain C-125 AscI (A) fragments and corresponding Sse8387I (S) fragments. (i) and (ii) show two sets of linked fragments. (iii) and (iv) show AscI fragments that remain unlinked. Fragment numbers correspond to their allotted band numbers as given in Table 1 . The $4 \mathrm{~S}$ and $12 \mathrm{~S}$ fragments are represented by dotted lines as their actual positions in relation to the corresponding $A s c \mathrm{I}$ fragments are unknown. The correct orientations of the 13A and 17A doublet, the $r r n$ and $x y l(\mathrm{~N})$ on $3 \mathrm{~A}$ or $6 \mathrm{~S}$, the rrn and $\sec \mathrm{Y}$ on $4 \mathrm{~A}$ or $3 \mathrm{~S}$, and the pALK and pNEXT39 on 1A or $2 \mathrm{~S}$ are unknown.

Table 4. Hybridization patterns of probes to restriction endonuclease fragments of Bacillus sp. strain C-125 DNA

Fragments generated with either $A s c I$ or $S s e 8387 \mathrm{I}$ are identified by their band numbers (Table 1). The $A s c I$ plus $S s e 8387$ I fragments and fragments generated as a result of partial $A s c I$ or Sse8387I digestion are identified by their sizes in $\mathrm{kb}$.

\begin{tabular}{|c|c|c|c|c|c|}
\hline \multirow[b]{3}{*}{ Probe } & \multicolumn{5}{|c|}{ Hybridization with fragment } \\
\hline & \multirow[b]{2}{*}{$A s c \mathrm{I}$} & \multirow[b]{2}{*}{ Sse8387I } & \multirow{2}{*}{$\begin{array}{c}\text { Ascl-plus- } \\
\text { Sse8387I }\end{array}$} & \multicolumn{2}{|c|}{ Partial digests of } \\
\hline & & & & $A s c \mathrm{I}$ & Sse83871 \\
\hline$u n c \mathrm{H}, \mathrm{A}, \mathrm{G}$ & $6 \mathrm{~A}$ & 1S & 200 & - & - \\
\hline hag & $11 \mathrm{~A}$ & $1 \mathrm{~S}$ & $11 \mathrm{~A}$ & - & - \\
\hline pALK & $1 \mathrm{~A}$ & $2 S$ & 470 & - & 580 \\
\hline \multirow[t]{3}{*}{$23 \mathrm{~S} r r$} & $3 \mathrm{~A}$ & $6 S$ & - & - & - \\
\hline & $15 \mathrm{~A}$ & $4 \mathrm{~S}$ & - & - & - \\
\hline & $4 \mathrm{~A}$ & $3 S$ & - & - & - \\
\hline \multirow[t]{2}{*}{$\sec \mathrm{Y}$} & $4 \mathrm{~A}$ & $3 S$ & 230 & 460 & - \\
\hline & & & & 580 & - \\
\hline$x y l(\mathrm{~A})$ & $5 \mathrm{~A}$ & $17 \mathrm{~S}$ & - & 640 & 245 \\
\hline$x y l(\mathrm{~N})$ & $3 \mathrm{~A}$ & $6 \mathrm{~S}$ & 150 & - & - \\
\hline $\operatorname{trpS}$ & $8 \mathrm{~A}$ & $7 \mathrm{~S}$ & 140 & - & -. \\
\hline spollG & $7 \mathrm{~A}$ & $7 \mathrm{~S}$ & 45 & - & - \\
\hline pNEXT39 & $1 \mathrm{~A}$ & $2 S$ & 470 & - & - \\
\hline pNEXT41 & $7 \mathrm{~A}$ & $5 \mathrm{~S}$ & 150 & - & - \\
\hline 16A fragment & $16 \mathrm{~A}$ & $4 S$ & $16 \mathrm{~A}$ & 50 & - \\
\hline
\end{tabular}




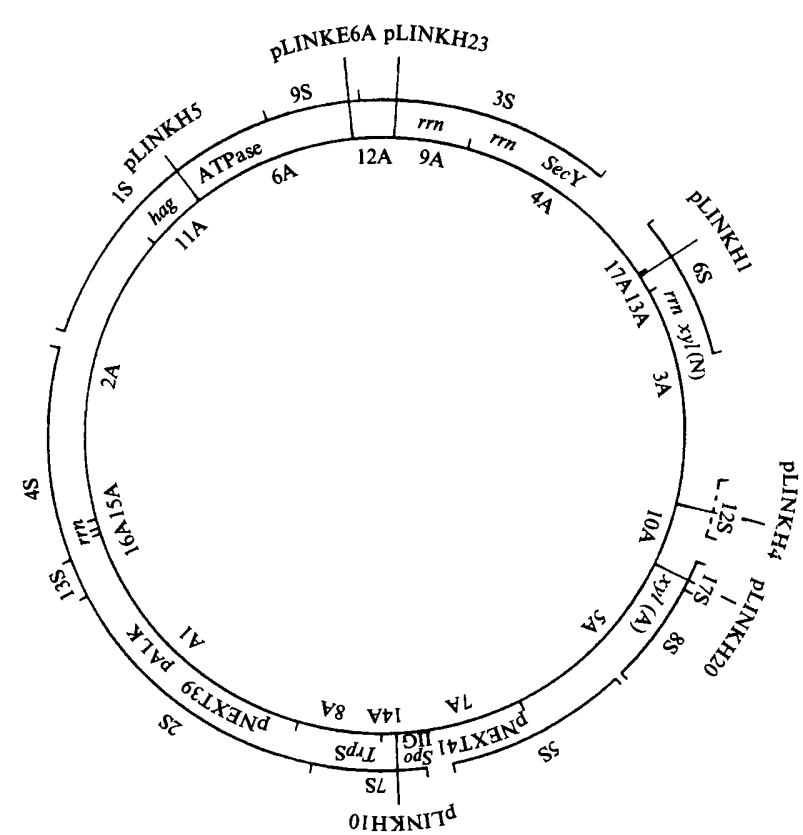

Fig. 5. Putative AscI physical map of the Bacillus sp. strain C-125 chromosome. Fragment numbers correspond to those listed in Table 1. The correct orientations of the 13A and 17A doublet, the 15A and 16A doublet, the $r r n$ and $x y l(\mathrm{~N})$ on $3 \mathrm{~A}$ or $6 \mathrm{~S}$, the $r r n$ and $s e c \mathrm{Y}$ on $4 \mathrm{~A}$ or $3 \mathrm{~S}$, and the pALK and pNEXT39 on 1A or $2 \mathrm{~S}$ are unknown.

map that fits all our data, represents the chromosome of Bacillus sp. strain C-125.

The allotted positions of cloned genes on the putative chromosome map of Bacillus sp. strain C-125 compare favourably with their positions on the genetic and physical maps of B. subtilis (Piggot \& Hoch, 1991; Itaya \& Tanaka, 1991). The corresponding starting point of the Bacillus sp. strain C-125 can thus be tentatively assigned to the $9 \mathrm{~A}$ or possibly the $12 \mathrm{~A}$ fragment. Only the $\operatorname{trpS}$ gene appears to have a divergent map position, being located at 104 min on the $B$. subtilis genetic map (Piggot \& Hoch, 1991) and approximately $180 \mathrm{~min}$ on the proposed Bacillus sp. strain C-125 map. The similarity of the putative Bacillus sp. strain C-125 genetic map to that of $B$. subtilis is encouraging, and suggests that gene order on the chromosomes of closely related organisms is conserved.

We are very grateful to Dr M. Itaya for many helpful and useful discussions. We thank Drs H. Honda, M. Itaya, S.-K. Kang and T. Kobayashi for the probes supplied. We also thank the Science and Technology Agency of Japan for a fellowship to K.J.S. This work was partially supported by a grant for the Biodesign Research Program from RIKEN to T. Kudo.

\section{References}

Birkelund, S. \& STEPHENS, R. S. (1992). Construction of physical and genetic maps of Chlamydia trachomatis serovar L2 by pulsed-field gel electrophoresis. Journal of Bacteriology 174, 2742-2747.

Chen, H., Kuspa, A., Keseler, I. M. \& Shimkets, L. J. (1991). Physical map of the Myxococcus xanthus chromosome. Journal of Bacteriology 173, 2109-2115.

Chow, K.-C. \& Wong, T.-F. (1988). Cloning and nucleotide sequence of the structural gene coding for Bacillus subtilis tryptophanyl tRNA synthetase. Gene 73, 537-543.

Fonstein, M., Zheng, S. \& HASelkorn, R. (1992). Physical map of the genome of Rhodobacter capsulatus SB 1003. Journal of Bacteriology 174, 4070-4077.

Honda, H., KuDo, T. \& Horikoshi, T. (1985). Molecular cloning and expression of the xylanase gene of alkalophilic Bacillus sp. strain C125 in Escherichia coli. Journal of Bacteriology 161, 784-785.

HoRIKosHI, K. (1991) In Microorganisms in Alkaline Environments, pp. 5-24. Tokyo: Kodansha.

ItAya, M. \& TANAKA, T. (1991). Complete physical map of the Bacillus subtilis 168 chromosome constructed by a gene-directed mutagenesis method. Journal of Molecular Biology 220, 631-648.

KaNG, S.-K., KuDO, T. \& HoRIKoshI, K. (1992). Molecular cloning and characterization of an alkalophilic Bacillus sp. C-125 gene homologous to Bacillus subtilis secY. Journal of General Microbiology, 138, $1365-1370$.

Kolsto, A.-B., Gronstad, A. \& Oppegaard, H. (1990). Physical map of the Bacillus cereus chromosome. Journal of Bacteriology 172, 3821-3825.

Krause, D. C. \& Mawn, C. B. (1990). Physical analysis and mapping of the Mycoplasma pneumoniae chromosome. Journal of Bacteriology 172, 4790-4797.

Kudo, T., Hino, M., Kitada, M. \& Horikoshi, K. (1990). DNA sequences required for the alkalophily of Bacillus sp. C-125 are located close together on its chromosomal DNA. Journal of Bacteriology 172, 7282-7283.

Piggot, P. J. \& Hoch, J. A. (1989). Revised genetic map of Bacillus subtilis 168. In Regulation of Procaryotic Development, pp. 1-41. Edited by I. Smith, R. Slepecky, \& P. Setlow. Washington, DC: American Society for Microbiology.

RömLING, U. \& TüMmLeR, B. (1991). The impact of two-dimensional pulsed-field gel electrophoresis techniques for the consistent and complete mapping of bacterial genomes: refined physical map of Pseudomonas aeruginosa PAO. Nucleic Acids Research 19, 3199-3206.

Römling, U., Grothues, D., Bautsch, W. \& TÜmmler, B. (1989). A physical genome map of Pseudomonas aeruginosa PAO. EMBO Journal 8, 4081-4089.

SaITo, H. \& MiURa, K. (1963). Preparation of transforming DNA by phenol treatment. Biochemica et Biophysica Acta 72, 619-629.

SaKamoto, Y.-I., Sutherland, K. J., TamaOKa, J., Kobayashi, T., Kudo, T. \& Horikoshi, K. (1992). Analysis of the flagellin (hag) gene of alkalophilic Bacillus sp. C-125. Journal of General Microbiology 138, 2159-2166.

SambrooK, J., Fritsch, E. F. \& Maniatis, T. (1989). Molecular Cloning: a Laboratory Manual, 2nd edn. Cold Spring Harbor, NY: Cold Spring Harbor Laboratory.

SMith, C. L. \& CONDEMINE, G. (1990). New approaches for physical mapping of small genomes. Journal of Bacteriology 172, 1167-1172.

Stagier, P., Bouvier, J., Bonamy, C. \& Szulmajister, J. (1984). A developmental gene product of Bacillus subtilis homologous to the sigma factor of Escherichia coli. Nature, London 312, 376-378.

Taylor, D. E., Eaton, M., Yan, W. \& Chang, N. (1992). Genome maps of Campylobacter jejuni and Campylobacter coli. Journal of Bacteriology 174, 2332-2337.

YAN, W. \& TAYLOR, D. E. (1991). Sizing of the genome of Campylobacter coli strain UA417R. Gene 101, 117-120. 